\title{
Effect of certain flavour-improving treatments of recombined-fresch milk blend on its heat stability
}

\author{
R.M. JOSHI, A.A. PATEL and B.N. MATHUR \\ Division of Dairy Technology, National Dairy Research Institute \\ Karnal 132001 , India
}

\begin{abstract}
Résumé
Effet sur la stabilité thermique des mélanges lait frais-lait reconstitué des traitements destinés à améliorer leurs qualités organoleptiques
\end{abstract}

Des modifications mineures de composition ainsi que l'addition de sucrose, de citrate de sodium ou de diacétyle améliorent l'acceptabilité des mélanges 50:50 lait frais-lait reconstitué. Les effets de ces modifications et de ces additions sur la stabilité thermique des mélanges finals ont été étudiés. L'accroissement de $2 \%$ de la teneur en substance sèche non grasse diminue fortement la stabilité thermique mesurée par le temps de coagulation à $120^{\circ} \mathrm{C}$ (méthode des tubes capillaires). Au contraire, l'addition des trois substances indiquées plus haut accroît le temps de coagulation thermique ; la stabilité maximale est obtenue par l'addition de citrate, la moins élevée par l'addition de sucrose.

Mots clés : Lait reconstitué - Lait de mélange - Stabilité thermique - Sucrose - Diacétyle - Citrate - Teneur en susbtance sèche.

Key words : Recombined milk - Blended milk - Heat stability - Additives - Solidsnot-fat.

\section{Introduction}

The off-flavour of recombined milk rendering is less acceptable than fresh milk generally warrants the milk to be blended with fresh milk (SANDERson, 1970). The flavour acceptability of such milk can be further enhanced by minor compositional modifications as, for example, increasing the solids - not - fat (SNF) content, or by using small quantities of certain additives viz., sodium citrate, sucrose and diaceyt (Joshr et al., 1986). Stabilizing salts such as sodium citrate have been observed to improve the heat stability of milk (WEBB and HoLM, 1932 ; SWeETSUR and Muir, 1980a). However, no information is available on the effect of such additives in respect of recombined milk. 
Furthermore, sucrose and diacetyl do not seem to have attracted any research attempts with regard to their ability to stabilize the milk colloid except that SweEtsur and MuIR (1980b) found no destabilizing effect of non-reducing carbohydrates such as sucrose, unlike reducing ones, added to skimmilk concentrates obtained by ultrafiltration. JoNGH et al. (1978) observed decreasing heat stability with an increasing SNF content of recombined evaporated milk in the range of 16-22 \% SNF. However, the heat stability of recombined milk as influenced by relatively small increases in its SNF content has not been investigated. This report discusses the heat stability of recombined milk blended with fresh milk $(50: 50)$ and modified with respect to its flavour by increasing its SNF content by upto $2.0 \%$ or by incorporating the above-mentioned additives without $\mathrm{pH}$ adjustment.

\section{Materials and methods}

\section{Blended milk and additives}

A 50:50 blend of recombined milk and fresh pasteurized milk (3.0\% fat and $8.5 \%$ SNF) was prepared as described earlier (JosH et al., 1986). Required quantities of trisodium citrate (IP/BP, Sarabhai, India) and white, refined canesugar were dissolved in a small amount of distilled water prior to their addition to milk, whereas diacetyl (Sigma, USA) was incorporated as $0.01 \%$ solution in distilled water.

\section{Heat stability}

The subjective method of DAvies and White (1966) employing $10.0 \mathrm{~cm}$ long Pyrex glass tubes (i.d. $0.8 \mathrm{~cm}$ ) containing $1 \mathrm{ml}$ milk and closed with rubber stoppers at both ends was used. A liquid paraffin-bath fitted with a mount (for 20 tubes) attached to a rotary (up-and-down) mechanism (8 cycles/min) was used and the heat stability expressed as heat coagulation time (HCT) in minutes (at $120^{\circ} \mathrm{C}$ ).

\section{Results and discussion}

The HCT blended milk (218.0 min) was lower than that for fresh milk alone (246.0) but higher than the HCT for recombined milk (195.7), the difference being statistically significant $(\mathrm{P}<0.01$; Critical Difference $=2.86)$. GRIFFIN et al. (1976) reported somewhat higher heat stability fo recombined milk as compared to fresh bulk milk. Such a contradiction in results may be attributed to the wide variability of the heat stability of milk (Fox and MORRISSEY, 1977). Pronounced influence of the pre-heat treatment (prior to drying) on the heat stability of reconstituted milk (SweEtsur and Muir, 1980 a) also cannot be disregarded as a possible reason for the anomalous results. 


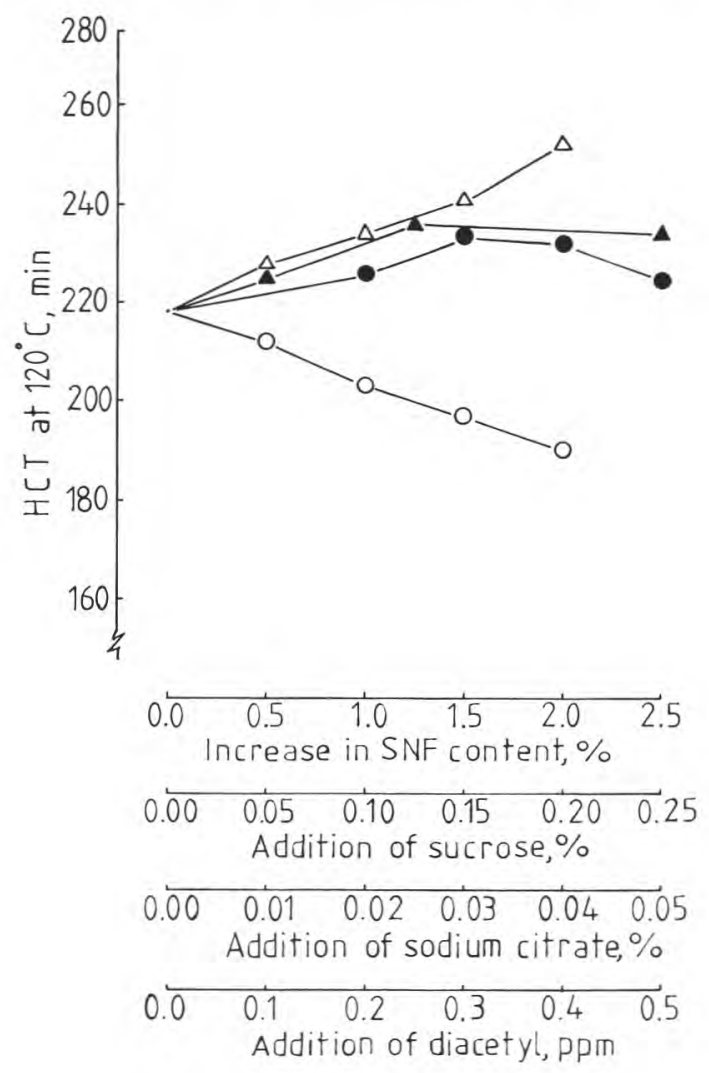

Fig. 1

Effect of flavour-improving treatments on the heat stability of recombined-fresh milk $(50: 50)$ blend-- $(0)$ solids-not-fat, $(\bullet)$ sucrose, $(\triangle)$ sodium citrate, $(\mathbf{A})$ diacetyl.

Effets de l'accroissement de la teneur en substance sèche non grasse $(0)$ et de l'addition de sucrose $(\bullet)$, de diacétyle $(\mathbf{\Delta})$ et de citrate de $N a(\Delta)$ sur la stabilité thermique des mélanges de lait frais et de lait reconstitué.

The heat stability of blended milk as affected by different treatments has been depicted in figure 1. It follows therefrom that while increased SNF resulted in decreased HCT, the use of additives had the opposite effect.

The HCT declined appreciably with the increasing level of SNF. Even the smallest increase (corresponding to $9.0 \% \mathrm{SNF}$ in the milk) caused a statistically significant $(\mathrm{P}<0.01)$ decrease in HCT, and the milk with $2.0 \%$ increase in SNF showed $12.8 \%$ lower HCT as compared to the milk with $8.5 \%$ SNF. A generally inverse relationship between the SNF content and heat stability has been recorded for concentrated milk (WEBB and HoLM, 1932) and recombined milk concentrates (JoNGH et al., 1978). However, the changes observed in the present study were less dramatic, probably because of lower concentration of SNF. A variety of 
factors known to affect the heat stability of milk such as pH (Rose, 1961), relative concentrations of soluble and colloidal salts (MORRISSEY, 1969) and zeta potential (Fox and MoRRISSEY, 1977) are likely to be influenced by changes in the concentration of SNF, and this can be taken to account for the SNF-induced changes in the HCT of the blended milk of the present study.

While all the additives examined tended to improve the heat stability of the milk, sucrose was found to be the least effective among them. Increasing concentration of sucrose upto $0.15 \%$ resulted in increasing HCT, but further increase caused a decrease in HCT. Nevertheless, $0.25 \%$ sucrose giving the lowest increase in HCT gave a blended milk which was significantly more heat stable than that without any sucrose addition. Certain pentoses and hexoses added in small quantities have been observed to influence the heat stability of milk (HoLT et al., 1978 ; GHATAK et al., 1980), but the effect of sucrose has not been reported. Sucrose $(19 \%)$ added to skimmilk concentrates from ultrafiltration has, however, been found not to cause any appreciable alteration in the heat stability of the resulting mixtures (SWEETSUR and MUTR, 1980b).

Figure 1 further shows that over the whole range of sodium citrate concentrations studied, the heat stability improved nearly proportionately with the concentration. The increase was statistically significant at each successive level, the highest level giving an overall increase of $15.6 \% \mathrm{HCT}$. Stabilizing salts such as citrate and phosphate have been reported to be generally beneficial in enhancing the colloidal stability of milk to heat (WEBb and HoLm, 1932 ; SweETsur and MuIR, 1980a). Rose (1861) showed that maximum heat stability was significantly negatively correlated with the ratio of soluble calcium to soluble phosphate and with the ratio of ionic calcium to soluble phosphate, both of which can be expected to be affected by the addition of citrate or phosphate. According to Mohammad and Fox (1983), binding of calcium ions and removal of colloidal calcium phosphate from the casein micelle by the added citrate could be responsible for the stabilizing effect of the salt. Alteration in the $\mathrm{pH}$ of milk caused by the stabilizer might at least partly be responsible for the observed change in heat stability.

It is interesting to note that incorporation of diacetyl also brought about significant improvement in heat stability, the $0.25 \mathrm{ppm}$ level being most effective. Added at $0.50 \mathrm{ppm}$, it resulted in a slightly but not significantly lower HCT than that with $0.25 \mathrm{ppm}$.

\section{Conclusion}

Small increases in the SNF content resulted in significantly decreased heat stability of blended milk. Addition of sucrose, sodium citrate and diacetyl, on the other hand, caused relatively small but significant increases in the HCT. These treatments, primarily intended to improve flavour acceptability of the milk, can be of practical importance if the milk has to be subjected to high heat treatment. A more significant implication of the present findings can be seen from the results of another study (JosHi and PATEL, 1986) indicating a definite negative correlation between the HCT and the tendency of milk to form heatinduced deposits on heat exchange surfaces. Use of the flavour-modifying addi- 
tives would thus also be helpful in retarding deposit formation during heat processing of recombined milk. The role of sucrose and diacetyl in stabilizing the milk colloid requires further investigations in relation to concentrated milks.

Thanks are due to Mr. D. Tikku, General Manager, Mother Dairy, Delhi for providing anhydrous milkfat and skimmilk powder for this study, and to the Indian Council of Agricultural Research, New Delhi for the award of Junior Fellowship to the first author.

Reçu le 19-8-1985.

Accepté pour publication le 15-12-1985

\section{References}

Davies D.T., White J.C.D., 1966. The stability of milk protein to heat : Subjective measurement of heat stability of milk. J. Dairy Res., 33, 67-81.

Fox P.F., Morrissey P.A., 1977. Reviews of the progress of dairy science : The heat stability of milk. J. Dairy Res., 44, 627-646.

Ghatak P.K., Singh A., Bhavdasan M.K., Ganguli N.C., 1980. The effect of addition of aldehydes or sugars on the heat stability of buffalo milk. N.Z.J. Dairy Sci. Technol., $15,159-165$.

Griffin A.T., Hickey M.W., BaIley L.F., Felagan J.T., 1976. The significance of preheat and $\mathrm{pH}$ adjustment in the manufacture of recombined evaporated milk. Aust. J. Dairy Technol., 31, 134-137.

Holt C., Muir D.D., Sweetsur A.W.M., 1978. The heat stability of milk and concentrated milk containing added aldehydes and sugars. J. Dairy Res., 45, 47-52.

JoNgh M. DE, NewStead D.F., Hughes I.R., BaLdWin A.J., 1978. Effect of SNF, fat and homogenization pressure on the heat stability of recombined evaporated milk. N.Z.J. Dairy Sci. Technol., 13, 242-244.

Joshi R.M., Patel A.A., MathuR B.N., 1986. Improving the flavour acceptability of recombined milk blended with fresh milk. Lait, 66 (in press).

Joshi R.M., Patel A.A., 1986. Heat-induced deposit formation and its relationship to heat stability in recombined-fresh milk blend. J. Dairy Res., 53, 323-327.

Moнammad K.S., Fox P.F., 1983. Influence of some polyvalent organic acids and salts on the colloidal stability of milk. J. Soc. Dairy Technol., 36, 112-117.

MoRRISSEY P.A., 1969. Heat stability of milk as affected by variations in pH and milk salts. J. Dairy Res., 36, 343-351.

ROSE D., 1961. Variations in the heat stability and composition of milk from individual cows during lactation. J. Dairy Sci., 44, 430-441.

SANDERSON W.B., 1970. Reconstituted and recombined dairy products. N.Z.J. Dairy Sci. Technol., 5, 139-143.

SweETSUR A.W.M., MUIR D.D., 1980 a. The use of permitted additives and heat treatment to optimise the heat stability of skimmilk and concentrated skimmilk. J. Soc. Dairy Technol., 33, 101-105.

SweEtsur A.W.M., MUIR D.D., 1980 b. Properties of concentrates containing milk protein and non-milk carbohydrates. J. Food Technol., 15, 533-542.

Webi B.H., HoLm G.E., 1932. The heat coagulation of milk. II. The influence of various added salts upon the heat stabilities of milks of different concentrations. $J$. Dairy Sci, $15,345-366$. 